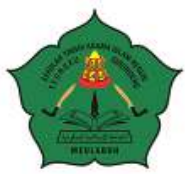

AT-TASYRI' Jurnal Ilmiah Prodi Muamalah

P-ISSN: 2085-2541, E-ISSN: 2715-7865

Volume 13, Nomor 2, Desember 2021

https://ejournal.staindirundeng.ac.id/index.php/Tasyri

\title{
PRODUK LEMBAGA KEUANGAN SYARIAH BERBASIS KEARIFAN LOKAL PRAKTEK "GALA UMONG" PADA MASYARAKAT ACEH
}

\author{
M. Aditya Ananda \\ Jurusan Syariah dan Ekonomi Islam, STAIN Teungku Dirundeng \\ adityasstai@outlook.com
}

\begin{abstract}
Abstrak
Praktek gala umong yang dilakukan ditengah masyarakat yang dilakukan secara tradisional tersedia padanan produk yang serupa secara terlembaga melalui PT Pegadaian Persero. Produk tersebut adalah rahan tasjily tanah. Produk ini bagian dari lini bisnis syariah yang menggunakan akad rahn tasjily. Hasil komparasi antara praktek gala umong dan produk rahan tasjily setidaknya terdapat 3 (tiga) perbedaan yaitu dari segi pemanfaatan barang gadaian, pola pembayaran serta jangka waktu. Pada praktek gala umong, pemanfaatan barang gadaian ada pada si penggadai sementara pada produk lembaga pegadaian, hanya menjaga hak kepemilikan atas barang gadaian. Selanjutnya perbedaan dari jangka waktu dan pembayaran. Adanya beberapa pola pembayaran yang ditawarkan yang dapat dipilih si penggadai sesuai kemampuannya seperti pola regular, pola fleksi dan berkala adapun tenor maksimal dibatasi selama 36 bulan. Sedangkan pada praktek gala umong, berakhirnya perjanjian mengikuti selesainya pembayaran kewajiban oleh debitur tanpa ketetapan jangka waktu tertentu.
\end{abstract}

Kata Kunci: Rahn, Rahn Tasjily, Marhun

Abstract

The practice of gala umong which is carried out in the community which is carried out traditionally is available as an equivalent of similar products in an institutionalized manner through PT Pegadaian Persero The product is rahan tasjily land. This product is part of the sharia business line that uses the Rahn Tasjily contract. The results of the comparison between the practice of gala umong and the product of rahan tasjily there are at least 3 (three) differences, namely in terms of the use of the mortgaged goods, payment patterns and time periods. In the practice of gala umong, the use of the pawned goods is with the pawner, while the products of the pawnshop only maintain ownership rights to the pawned goods. The next difference is the term and payment. There are several payment patterns offered that the pawner can choose according to his abilities, such as regular patterns, flexion patterns and periodicals, while the maximum tenor is limited to 36 months. Whereas in the practice of gala umong, the end of the agreement follows the completion of payment of obligations by the debtor without a certain period of time.

Keywords: Rahn, Rahn Tasjily, Marhun

\section{A. PENDAHULUAN}

Dalam kehidupan sudah kodratnya kebutuhan dan keinginan tersebut tidak dimana adakalanya sebagai manusia dihadapi dengan kesulitan keuangan, kebutuhan mendapat dukungan dengan sumber daya mengembangkan usaha maupun keinginan yang cukup sehingga mengakibatkan permasalahan. Permasalahan-permasalahan yang bersifat konsumtif. Kenyataanya, yang timbul ini dipandang dalam ilmu 
ekonomi sebagai masalah ekonomi. ${ }^{1}$ Untuk menghadapi permasalahan ini dalam jangka pendek, biasanya manusia salah satunya mengambil keputusan untuk melakukan pinjaman utang baik melalui individu maupun pada lembaga keuangan terlebih jika kebutuhan bersifat mendesak. Kebutuhan dana dalam jumlah besar tentunya dalam proses pengajuan utang maka biasanya pihak kreditur meminta tambahan persyaratan kepada debiturnya. Tambahan persyaratan ini dapat dalam bentuk jaminan atau dalam bentuk apapun yang meyakinkan kreditur bahwa dana yang diberikan tetap terjamin pengembaliannya. Bentuk jaminan dapat beragam, jika ditinjau dari segi profesi calon debitur, bagi pekerja pada instansi swasta maupun pemerintahan, bentuk jaminan dapat berupa surat pengangkatan bekerja maupun dokumen lainnya yang disepakati sedangkan bagi pekerja wirawasta tentunya harus menyerahkan jaminan dalam bentuk lainnya yang memiliki nilai setara bahkan melebihi daripada pinjaman yang akan diambil. Kategori profesi yang terakhir disebutkan diatas, bila perjanjian disepakati maka jaminan yang diberikan akan dipindah tangan sementara selama proses pijaman tersebut berlangsung sebagaimana persyaratan dalam perjanjian gadai maupun rahn mensyaratkan adanya penyerahan harta baik harta bergerak maupun tidak bergerak sebagai yang dijaminkan.

Profesi wiraswasta ditinjau dari demografi sudah alamiyah tentunya terdapat baik diwilayah perkotaan maupun wilayah pedesaan. Bagi pekerja sektor formal, perjanjian gadai dengan penyerahan jaminan yang akan dipindahkan sementara tentunya tidak akan berpengaruh terhadap keberlangsungan mata pencarian, namun hal ini belum tentu berlaku serupa bagi calon debitur pada wilayah pedesaan yang mayoritas bermata pencarian agraris dengan mengandalkan pertanian. Pekerja pada sektor pertanian lumrahnya memiliki asset dalam bentuk harta tidak bergerak seperti tanah sawah maupun kebun. Bagi profesi ini, penyerahan asset kepada kreditur sebagai barang jaminan berpotensi mengancam keberlangsungan mata pencarian, karena aset tersebut merupakan sumber mata pencarian utamanya.

Praktek gala umong yang berlangsung ditengah masyarakat merupakan salah satu bentuk dari pada perjanjian gadai. Pada perjanjian ini, barang yang dijaminkan berupa tanah sawah akan diserahkan pemeliharaannya dan memanfaatkannya pada kreditur selama praktek gala umong ini mengikat pihak yang mengikat perjanjian. ${ }^{2}$ Praktek gadai ini telah menjadi lazim dilakukan dimasyarakat pedesaan diwilayah Aceh. Apa yang dipaparkan diatas hanya menyoroti sebatas pemanfaatan harta jaminan. Beberapa aspek lain dapat dilihat dari beberapa hasil penelitian yang pernah dilakukan. Penelitian yang dilakukan oleh safrizal diwilayah desa gampong dayah syarif kecamatan mutiara pidie menyimpulkan bahwa praktek gadai yang dilakukan pada lokasi penelitian belum memenuhi rukun dan persyaratan rahn, serta peneliti menyorot pemanfaatan hasil barang gadai yang berpotensi mengeksploitasi sebelah pihak ${ }^{3}$ Hasil penelitian Muhammad iqbal dan Sukirno yang berjudul rekontruksi perjanjian gala (gadai adat) pada masyarakat adat Aceh

\footnotetext{
${ }^{1}$ N. Gregory Mankiw, Pengantar Ekonomi Mikro, edisi7, terjemahan Crishwan Sungkono, Jakarta: Salemba Empat, 2018, H.4

${ }^{2}$ Azharsyah Ibrahim, Praktek Ekonomi Masyarakat Aceh dalam konteks Ekonomi Islam: Kajian terhadap system Mawah dan Gala, dalam Proceding of the Aceh Development International Conference 2012

${ }^{3}$ Safrizal, Praktek Gala Umong (Gadai sawah) dalam perspektif syariah : studi kasus didesa Gampong dayah syarif kecamatan mutiara kabupaten pidie provisi Aceh. Dalam jurnal Islam Futura vol 15, No.2 Februari 2016.
} 
berbasis syariah ialah praktek gadai (gala) dilakukan dalam konteks keadaan mendesak kekurangan financial bagi pihak yang akan menggadaikan hartanya. Penelitian ini juga menyoroti mengenai temuan adanya perjanjian gadai yang dilakukan dengan tanpa ketentuan waktu berakhirnya perjanjian. ${ }^{4}$ Dari hasil penelitian tersebut, penulis mencoba mengkomparasikan antara jasa gadai yang tawarkan secara tradisional dengan produk gadai yang ditawarkan melalui lembaga gadai yang dibentuk secara formal. Apakah lembaga pegadaian melakukan perjanjian yang identik dengan gala umong? Yang terpenting, apakah lembaga pegadaian terdapat produk yang menawarkan jasa yang serupa praktek gala umong.

\section{B. KAJIAN PUSTAKA}

\section{Gala umong, gadai dan rahn}

Gala merupakan praktek ekonomi di Aceh yang telah berlangsung lama. Praktek ekonomi yang dilakukan dalam bentuk pinjaman dengan dasar menggadaikan harta yang dimiliki untuk memenuhi kebutuhan financial yang sifatnya mendesak. ${ }^{5}$ Adapun umong memiliki padanan kata yang serupa dengan 'tanah sawah'. Istilah gala umong menunjukan praktek perjanjian gadai dimana tanah sawah menjadi objek jaminan dalam perjanjian tersebut. Awalnya praktek ini tidak tertulis namun seiring waktu mulai dilakukan perjanjian secara tertulis namun jangka waktu tanpa ketentuan berakhirnya perjanjian. ${ }^{6}$ Perjanjian gala yang dipraktekan di Aceh dapat dipersamakan dengan perjanjian gadai. ${ }^{7}$ Adapun gadai dalam fiqih muamalah dikenal dengan perjanjian rahn. Namun terdapat perbedaan antara gadai dan rahn dalam beberapa aspek yang mana gadai menggunakan sistem bunga dan biaya gadai ditetapkan diakhir dan biaya berpotensi bertambah adapun rahn sebaliknya. ${ }^{8}$

Rahn dapat didefinisikan penahanan terhadap suatu barang dengan hak sehingga dapat dijadikan sebagai pembayaran dari barang tersebut. ${ }^{9}$ Rahn terbagi kepada dua bentuk, rahn tasjily dan rahn hiyazi. rahn tasjily merupakan bentuk gadai dengan pemindahan bukti kepemilikan adapun rahn hiyaji merupakan bentuk gadai yang mana harta yang digadaikan dalam penguasaan sipenerima gadai. Rahn tasjily lebih mendekati jaminan fidusia. ${ }^{10}$ Fidusia berasal dari kata fides, yang artinya kepercayaan. Fidusia merupakan pengalihan hak kepemilikan suatu benda atas dasar kepercayaan dengan ketentuan bahwa benda yang hak kepemilikannya dialihkan tersebut tetap dalam penguasaan pemilik benda. ${ }^{11}$

Syarat rahn dapat dibagi menjadi 5 (lima), pertama, syarat bagi yang melakukan akad. kedua, syarat ijab qabul, syarat marhun bih, syarat marhun, syarat sempurna akad rahn yaitu al-Qabdhu. Al-qabdhu ialah penyerahan marhun oleh rahin kepada murtahin. Fuqaha

\footnotetext{
${ }^{4}$ Muhammad Iqbal, Sukirno, Rekontruksi Perjanjian Gala (Gadai Adat) pada Masyarakat Adat Aceh Berbasis Syariah, dalam jurnal Law reform, volume 13 nomor 1 Tahun 2017.

${ }^{5}$ Azharsyah Ibrahim, Praktek Ekonomi Masyarakat Aceh dalam konteks Ekonomi Islam: Kajian terhadap system Mawah dan Gala, dalam Proceding of the Aceh Development International Conference 2012

${ }^{6}$ Azharsyah Ibrahim, Praktek Ekonomi Masyarakat Aceh dalam konteks Ekonomi Islam: Kajian terhadap system Mawah dan Gala, dalam Proceding of the Aceh Development International Conference 2012

${ }^{7}$ Muhammad Iqbal, Sukirno, Rekontruksi Perjanjian Gala (Gadai Adat) pada Masyarakat Adat Aceh Berbasis Syariah, dalam jurnal Law reform, volume 13 nomor 1 Tahun 2017.

8 Ridwan Nurdin, Akad - akad fiqih pada perbankan syariah di Indonesia (Sejarah Konsep dan Perkembangannya), Banda Aceh: Penerbit PeNA, 2010, h. 95

${ }^{9}$ Rachmat Syafei, Fiqih Muamalah, Bandung Pustakan Setia, 2001, h. 159

${ }^{10}$ Tri Hidayati, dkk, Mekanisme penggunaan Jaminan Kebendaan (Rahn Tasjily) dalam Pmbiayaan Bank Syariah di Indonesia dan Malaysia, dalam jurnal Nurani Vol 18, No.1 Juni 2018

${ }^{11}$ Undang - undang No. 42 tahun 1999 Tentang Jaminan Fidusia
} 
bersepakat bahwasanya al qabdhu merupakan syarat rahn. Hal ini berdasarkan surat Albaqarah ayat 283, .........., 12

Penyerahan harta tidak bergerak dilakukan dalam bentuk penyerahan nyata atau dengan cara tahkliyah yaitu membiarkan marhun atas penguasaan murtahin, demikian kesepakatan fuqaha. Adapun untuk harta bergerak menurut ulama hanafiy juga cukup dengan takhliyah. Telah dilakukannya takhliyah maka rahin dianggap telah menyerahkan marhun kepada murtahin. Menurut Abu yusuf, alqabdhu atas barang bergerak tidak cukup hanya dengan takhliyat akan tetapi harus diikuti dengan an naqlu atau memindahkan. Sebelum adanya pemindahan, maka murtahin dianggap belum memegang marhun. Pendapat ini juga disepakati oleh ulama syafiiyah dan Hanabilah. ${ }^{13}$

Memberikan jaminan menggunakan segala bentuk medium sebagai ganti al-qabdhu hukumnya sah. Bentuk medium ini dapat berupa prosedur formalitas harta tidak bergerak dengan cara membubuhkan sebuah surat tanda harta oleh departemen pencatatan pertanahan melalui peraturan peundang undangan. ${ }^{14}$ contoh dari pada hal yang disebutkan diatas misalnya sertifikat kepemilikan tanah. Rahn inilah yang dikenal dengan istilah rahn tasjily. Rahn Tasjily disebut juga rahn ta'mini, rahn rasmi, atau rahn hukmi yaitu jaminan dalam bentuk barang atas utang dengan perjanjian bahwa yang diserahkan hanya bukti kepemilikan adapun barang jaminan tersebut tetap dalam pemanfaatan si pemilik. ${ }^{15}$

\section{Pemanfaatan Barang Gadai}

Mengenai pemanfaatan barang yang sedang digadaikan atau marhun, ulama terbagi kepada dua pendapat. Pertama pendapat jumhur selain syafiiyah mengatakan rahin (sipenggadai) tidak boleh memanfaatkan barang yang sedang digadaikan. Pendapat ulama syafiiyah membolehkan memanfaatkan barang yang sedang digadaikan selama tidak merugikan si pemberi gadai (murtahin). ${ }^{16}$

Terdapat perbedaan antara rahn dan rahn tasjily. Pertama, pada marhun. Marhun yang diserah terimakan pada perjanjian rahn, merupakan barang yang memiliki nilai yang dapat diserahterimakan baik barang bergerak maupun barang tidak bergerak. Adapun pada rahan tasjily, yang menjadi objek penyerahan bukan barangnya akan tetapi bukti dari pada kepemilikan barangnya, adapun barang nya tetap pada penguasaan rahin. Perbedaan kedua ialah pada penguasaan atas marhun. Pada akad rahn, marhun dikuasai oleh murtahin adapaun pada rahn tasjily, penguasaan tanah tepa berada pada pihak rahin. ${ }^{17}$

Fukaha bersepakat bahwasanya biaya pemeliharaan garang gadai ditanggung oleh rahin. Adapun mengenai bentuk biaya pemeliharaan, ulama berbeda pendapat. Ulama hanafiyah berpendapat terdapat biaya menjadi bebang rahin dan ada biaya yang menjadi beban murtahin. Adapun menurut

${ }^{12}$ Wahbah Az-Zuhaili, Fiqih Islam 6, terjemahan Abdul Hayyie al-Kattani, dkk, cet.1 Jakarta: Gema Insani 2011, H.112-138

${ }^{13}$ Wahbah Az-Zuhaili, Fiqih Islam 6, terjemahan Abdul Hayyie al-Kattani, dkk, cet.1 Jakarta: Gema Insani 2011, H.140-141

${ }^{14}$ Wahbah Az-Zuhaili, Fiqih Islam 6, terjemahan Abdul Hayyie al-Kattani, dkk, cet.1 Jakarta: Gema Insani 2011, Hal. 142

${ }^{15}$ Fatwa Dewan Syariah Nasional No:68/DSN-MUI/III2008 tentang Rahn Tasjily

${ }^{16}$ Wahbah Az-Zuhaili, Fiqih Islam 6, terjemahan Abdul Hayyie al-Kattani, dkk, cet.1 Jakarta: Gema Insani 2011, Hal. 221

${ }^{17}$ Rahmadi Indra Tektona dan Dyah ochtorina Susanti, Akad Rahn Tasjily pada gadai Tanah Pertanian di Pegadaian Syariah dalam jurnal Asy-Syari'ah Vol 22, No. 22020 
jumhur ulama berpendapat seluruh biaya menjadi tanggungjawab rahin. ${ }^{18}$

Berakhirnya akad rahn disebabkan beberapa hal yaitu diserahkan barang gadai kepada pemiliknya, sipenggadai telah menyelesaikan kewajibannya, marhun terpaksa dijual oleh sipenggadai atas perintah hakim, sipenggadai terbebas dari kewajibannya dengan cara apapun, pembatalan rahn dari pihak pemberi gadai, sipenggadai meninggal dunia sebelum terjadinya penyerahan barang gadaian, barang gadaian binasa, dan barang gadaian disedekahkan atas izin pihak lain. ${ }^{19}$

\section{DATA DAN METODOLOGI}

Penelitian ini menggunakan metode penelitian conten Analysis, dengan menggunakan beberapa hasil penelitian pada topik yang sesuai dengan objek kajian. Data penelitian dihimpun melalui hasil penelitian yang menggambarkan objek kajian serta dikomparasikan dan dianalisis secara deskriptif. Adapun ruang lingkup kajian ialah perjajian gadai yang berlangsung dan dipraktek di masyarakat Aceh serta produk sepadan yang ditawarkan oleh PT pegadaian persero.

\section{HASIL DAN PEMBAHASAN}

\section{Profil PT Pegadaian Persero}

Lembaga keuangan dapat dibagi kepada dua kelompok, lembaga keuangan Bank dan lembaga keuangan bukan Bank. ${ }^{20}$ Lembaga keuangan yang kegiatan utamanya atas dasar hukum gadai dilakukan oleh lembaga pegadaian. Sebelum kemerdekaan, pemerintah saat itu telah membentuk lembaga gadai pada 1 April 1901. ${ }^{21}$ Lembaga gadai ini dinasionalisasi setelah era kemerdekaan pada tahun 1960. ${ }^{22}$ Perum pegadaian berubah bentuk menjadi PT pegadaian Persero melaui PP No. 51 Tahun 2011 tentang Perubahan bentuk Badan Hukum Perseroan umum pegadaian. Ditinjau dari historis, pegadaian telah ada lebih jauh dari dari tahun 1901, tepatnya pada masa pemerintahan colonial tahun 1746 dengan dibentuknya Bank Van Leening oleh VOC. ${ }^{23}$ Kronologi perubahan status pegadaian dapat dilihat berkut ini.

$$
\begin{aligned}
& \text { Kronologi perubahan status } \\
& \text { pegadaian }
\end{aligned}
$$

1961 Menjadi Perusahaan Negara melalui perpu No. 19 Tahun 1960 jo PP No. 178 tahun 1961

1969 Menjadi Perusahaan Jawatan melaui PP No 7tahun 1969

1990 Menjadi Perum berdasarkan PP No 10 tahun 1990 yang diperbarui melalui PP No. 103 Tahun 2000

2011 Menjadi Perseroan Terbatas melalui PP No. 51 Tahun 2011

2021 Holding Ultra Mikro dengan Induk PT Bank BRI Persero

Sumber: diolah dari laporan tahunan 2020

\footnotetext{
${ }^{18}$ Wahbah Az-Zuhaili, Fiqih Islam 6, terjemahan Abdul Hayyie al-Kattani, dkk, cet.1 Jakarta: Gema Insani 2011, Hal. $187-188$

${ }^{19}$ Wahbah Az-Zuhaili, Fiqih Islam 6, terjemahan Abdul Hayyie al-Kattani, dkk, cet.1 Jakarta: Gema Insani 2011, Hal. $229-231$

${ }^{20}$ Fatih Fuadi, Bank dan Lembaga Keuangan non Bank: teori dan Aplikasi, Indramayu: Penerbit Adab 2020, H.2

${ }^{21}$ Laporan Tahunan 2020 PT Pegadaian Persero

${ }^{22}$ M. Nur Rianto Al Arif, Lembaga Keuangan Syariah; Kajian Teoritis Praktis, Bandung: Penerbit Pustaka Setia, 2012, H. 276-277

${ }^{23}$ Laporan Tahunan 2020 PT Pegadaian Persero
} 
Produk dan jasa PT pegadaian Persero mencakup lima lini Bisnis yaitu pertama, Bisnis Gadai, kedua. Bisnis kedit mikro fidusia, Bisnis Syariah, keempat, bisnis Pembiayaan emas dan Bisnis jasa lainya. Bisnis gadai memiliki 3 produk dan jasa unggulan yaitu Pegadaian KCA, Pegadaian Krasida, dan Pegadaian gadai efek Konvensional. Bisnis Kredit Mikro fidusia memiliki dua produk yaitu Pegadaian kreasi dan Pegadaian Kresna. Adapun bisnis syariah, memiliki 4 produk yaitu Pegadaian Rahn, Pegadaian Rahn Tasjily Tanah, Pegadaian Arrum, dan pegadaian amanah. Bisnis pembiayaan Emas memiliki 2 produk yaitu pegadaian mulia dan pegadaian tabungan emas. Terakhir, Bisnis jasa lainnya memiliki 6 produk dan jasa meliputi pegadaian property, pegadaian MPO, pegadaian Jasa Taksiran, Pegadaian Jasa Titipan, pegadaian Remittance, dan pegadaian G-Lab. ${ }^{24}$ Diantara produk dan jasa yang ditawarkan dari lini bisnis yang telah dipaparkan diatas, maka peneliti akan menganalisa komparasi pada produk dari lini bisnis syariah yaitu produk rahn tasjily tanah. Produk rahn tanah ini tasjily mulai dikembangkan pada tahun 2018 oleh PT Pegadaian Persero.

\section{Perbandingan Produk}

Hasil penelitian akan mengemukakan jasa gadai yang semisal praktek gala umong yang dilakukan oleh masyarakat yang terdapat pada lembaga keuangan non Bank dan selanjutnya akan dikomparasikan dengan praktek yang berlaku dimasyarakat. Beberapa hal yang akan dianalis dan dikomparasikan mengenai apa yang dipraktikan dan berlangsung dimasyarakat Aceh ialah mengenai pemanfaatan barang gadai, jangka waktu, serta mekanisme pembayaran.

Pada tahap awal akan dianalisa mengenai pemanfaatan barang gadaian berdasarkan yang berlaku di masyarakat Aceh serta dikomparasikan dengan produk yang ditawarkan oleh PT Pegadaian Persero. Praktek yang berlangsung dimasyarakat dihimpun dari beberapa hasil penelitian. Pemanfaatan barang gadaian (gala) selama masa gadai berlangsung berada pada pihak si penerima gala (penerima gadai) dalam konteks fiqih muamalah yaitu murtahin. Barang gadaian yang biasanya berupa tanah persawahan akan berada pada pihak pemberi gadai selama gadai tersebut berlangsung, pihak pemberi gadai biasanya akan menggunakan lahan sawah tersebut sebagai bentuk balas jasa karena telah memberikan pinjaman kepada sipenggadai. ${ }^{25}$ Dari praktek yang berlaku dimasyarakat dapat dianalisa. Dalam kasus sipenggadai memiliki lahan sawah yang luas dan menggadaikan hanya beberapa dari lahan sawah yang dimilikinya tentunya tidak menjadi suatu permasalahan. Namun jika sipenggadai dalam kondisi lahan sawah yang digadaikan tersebut sebagai harta satu-satunya yang dimiliki ditambah lagi sebagai mata pencarian utama dari lahan yang digadaikan tersebut, maka tentunya hal ini akan menjadi sebuah permasalahan. Permasalahan akan timbul salah satunya ialah factor kesempatan dalam menyelesaikan kewajiban terhadap pihak yang memberikan gadai. Dimana kesempatan untuk menyelesaikan kewajiban menjadi tertutup hal ini disebabkan oleh karena sumber pencarian satu - satunya atau pencarian utamanya tidak dapat dimanfaatkan lagi karena sedang dalam status gadai. Hal ini berpotensi besar akan menjadi gagal bayar

\footnotetext{
${ }^{24}$ Laporan Tahunan 2020 PT Pegadaian Persero

${ }^{25}$ Azharsyah Ibrahim, Praktek Ekonomi Masyarakat Aceh dalam konteks Ekonomi Islam: Kajian terhadap system Mawah dan Gala, dalam Proceding of the Aceh Development International Conference 2012
} 
semakin besar dan menuntut si penggadai untuk beralih profesi dalam mata pencarian lain. Untuk kasus seperti ini tentunya akan sangat memberatkan bagi pihak sipenggadai.

Gala yang diterapkan dimasyarakat memiliki bentuk yang identik dengan apa yang ditawarkan oleh PT Pegadaian Persero. Melalui produk Rahn Tasjily Tanah, PT Pegadaian Persero menawarkan gadai tanah baik dalam bentuk sawah dimana sipenggadai masih dapat memanfaatkan harta yang digadaikannya, pihak si penerima gadai dalam hal ini lembaga pegadaian PT pegadaian Persero hanya mendapatkan jaminan dalam bentuk surat bukti kepemilikan atas harta yang digadaikan. Adapun ahansawah tersebut masih dapat dimanfaatkan bagi sipenggadai. Dalam kasus diatas, tentunya apa yang ditawarkan lembaga pegadaian lebih berrmanfaat bagi sipenggadai, sipenggadai masih dapat memanfaatkan harta tersebut sebagai mata pencariannya dan pada akhirnya sipenggadai memiliki kesempatan yang lebih besar untuk menyelesaikan kewajibannya kepada pihak sipenggadai. Produk rahan tasyjili tanah ini tentunya memiliki persyaratanyang lebih ketat dari pada praktek yang berlangsung dimasyarakat secara individu, dimana bukti kepemilikan harus memenuhi kriteria tertentu yang tekadang sulit dipenuhi sipenggadai diwilayah pedesaan dimana kemungkinan bukti kepemilikan harta tersebut tidak memenuhi sesuai kriteria persyaratan yang ditetapkan oleh lembaga pegadaian. Adapun beberapa kriteria persyaratan yang ditetapkan PT pegadaian persero sebagai berikut, tanah produktif yang mudah diakses, sertifikat tanah Asli, dan kelengkapan dokumen lainnya. ${ }^{26}$ Demikian gambaran kelengkapan sebagai persyaratan yang ditentukan pihak lembaga pegadaian. Kondisi ini terkadang menjadi pertimbangan bagi si penggadai untuk tetap menggadaikan lahan sawahnya secara tradisional dimana dari hal kelengkapan persyaratan bagi sebagian pihak dianggap lebih dimudahkan dari pada berhubungan dengan lembaga pegadaian formal.

Selanjutnya komparasi pada pola pembayaran. Pola pembayaran rahn Tasyjily pada PT Pegadaian Persero terdiri dari 3 pola. Pertama, pola regular. Kedua, pola Fleksi sekali Bayar, dan ketiga, Pola Berkala. Pola regular sebagaimana sistem pembayaran angsuran pada umumnya yang dibayarkan perbulan dalam tenor tertentu. Adapun pola fleksi, si peminjam dapat membayarkan keseluruhan setelah jangka waktu tertentu. Pola ini sangat cocok diterapkan bagi masyarakat yang berprofesi dibidang pertanian yang mana pembayaran secara keseluruhan dapat mengikuti masa panen hasil pertanian. Sedangkan pola berkala juga cocok digunakan bagi masyarakat petani dimana pembayaran pola ini tidak harus dilakukan secara keseluruhan namun dapat diterapkan mengikuti musim panen tanaman akan tetapi tetap dibatasi sampai tenor 3 tahun. Adapun biaya pemeliharan, PT Pegadaian persero menetapkan persentase tertentu dari taksiran barang gadaian sesuai pola pembayaran dan tenor yang telah disepakati. Adapun dari sisi jangka waktu, Perjanjian gala akan berakhir setelah si penggadai menyelesaikan kewajibannya, selama barang yang digadaikan belum ditebus, maka selama itu pula barang gadaian masih dalam pemanfaatan si penerima gadai, bahkan mencerminkan tanpa adanya pembatasan waktu tertentu atas perjanjian

${ }^{26}$ https://sahabatpegadaian.com dan https://pegadaiansyariah.co.id diakses pada tanggal 19 Juli 2021 pukul 19.20 
gala tersebut. ${ }^{27}$ Adapun produk PT Pegadaian persero menawarkan produk dengan batasan tenor dalam jangka waktu tertentu. Tenor maksimal yang ditawarkan oleh lembaga pegadaian ialah selama 36 bulan. $^{28}$

\section{E. KESIMPULAN}

Hasil penelitian menyimpulkan terdapat beberapa kemudahan yang ditawarkan melalui produk lembaga pegadaian jika dikomparasikan dengan perjanjian gala yang telah berlangsung selama ini secara tradisional. Pertama, pemanfaatan barang gadaian, produk yang ditawarkan PT Pegadaian persero melalui rahn tasjily tanah hanya menetapkan bukti kepemilikan yang sah sebagai marhun, adapun harta fisik masih bias dimanfaatkan oleh sipenggadai.

Pola pembayaran dan jangka waktu ditawarkan melalui beberapa pola pilihan dengan tenor yang dibatasi selama 36 bulan. Pilihan pembayaran dapat menyesuaikan dengan musim panen bagi sipenggadai yang berprofesi sebagai petani. Adapaun pola pembayaran tersebut ialah pola fleksi dan berkala yang mana pembayarannya dapat dilakukan dalam selang waktu beberapa bulan.

\section{DAFTAR PUSTAKA}

Al Arif, M. Nur Rianto. (2012) Lembaga Keuangan Syariah; Kajian Teoritis Praktis, Bandung: Penerbit Pustaka Setia

Az-Zuhailli, wahbah. (2011). Fiqih Islam. terjemahan Abdul Hayyie al-Kattani, dkk Jakarta: Gema Insani

Fatwa Dewan Syariah Nasional No:68/DSNMUI/III2008 tentang Rahn Tasjily
Hidayati, Tri dkk. (2018). Mekanisme penggunaan Jaminan Kebendaan (Rahn Tasjily) dalam Pmbiayaan Bank Syariah di Indonesia dan Malaysia. Jurnal Nurani Vol 18(1).

Iqbal, M dan Sukirno. (2017). Rekontruksi Perjanjian Gala (Gadai Adat) pada Masyarakat Adat Aceh Berbasis Syariah. Jurnal Law Reform Vol 13(1). 98-113

Ibrahim, Azharsyah. (2012). Praktek Ekonomi Masyarakat Aceh dalam konteks Ekonomi Islam: Kajian terhadap system Mawah dan Gala,. Proceding of the Aceh Development International Conference 2012

Mankiw, N. Gregory . (2018) Pengantar Ekonomi Mikro, edisi7, terjemahan Crishwan Sungkono, Jakarta: Salemba Empat

Nurdin, Ridwan. (2010). Akad - akad fiqih pada perbankan syariah di Indonesia (Sejarah Konsep dan Perkembangannya), Banda Aceh: Penerbit PeNA

PT pegadaian Persero, Laporan Tahunan 2020 PT Pegadaian Persero

Syafei, Rahchmat. (2001). Fiqih Muamalah. Bandung: Pustaka Setia

Safrizal. (2016). Praktek Gala Umong (Gadai sawah) dalam perspektif syariah: studi kasus di desa gampong dayah syarif kecamatan mutiara kabupaten pidie provinsi Aceh. Jurnal Islam Futura Vol 15(2). 231-250

Tektona, Rahmadi Indra dan Dyah ochtorina Susanti, Akad Rahn Tasjily pada gadai Tanah Pertanian di Pegadaian Syariah jurnal Asy-Syari'ah Vol 22, ( 2) 179196

Undang - undang No. 42 tahun 1999 Tentang Jaminan Fidusia

\footnotetext{
${ }^{27}$ Safrizal, Praktek Gala Umong (Gadai sawah) dalam perspektif syariah : studi kasus didesa Gampong dayah syarif kecamatan mutiara kabupaten pidie provisi Aceh. Dalam jurnal Islam Futura vol 15, No.2 Februari 2016

${ }^{28}$ https://pegadaiansyariah.co.id diakses pada tanggal 19 Juli 2021 pukul 19.55
} 